\section{Scientific drilling of a cold-water carbonate mound: Shipboard biogeochemical results from IODP Expedition 307}

T.G. Ferdelman ${ }^{1}$, A. $\mathrm{KANO}^{2}$, T. Williams ${ }^{3}$, B.A. $\mathrm{CragG}^{4}$, T.D. FranK ${ }^{5}$, J.J. GHARIB ${ }^{6}$, P. LÉONIDE ${ }^{7}$, K. MANGElSDORF ${ }^{8}$, S. SAKAI ${ }^{9}$, V.A. SAMrikin ${ }^{10}$, A.J. Spivack ${ }^{11}$, The IODP Expedition 307 Scientific Party

${ }^{1}$ Max-Planck-Institute for Marine Microbiology, Bremen (tferdelm@, mpi-bremen.de)

${ }^{2}$ Hiroshima University (kano@geol.sci.hiroshima-u.ac.jp)

${ }^{3}$ Lamont-Doherty Earth Observatory of Columbia University (trevor@1deo.columbia.edu)

${ }^{4}$ Cardiff University (b.cragg@earth.cardiff.ac.uk)

${ }^{5}$ University of Nebraska (tfrank2@unl.edu)

${ }^{6}$ University of Hawaii (gharib@hawaii.edu)

${ }^{7}$ Unviersité de Provence (leoninde@up.univ-mrs.fr)

${ }^{8}$ Geo Forschungs Zentrum, Potsdam (k.mangelsdorf@gfz-potsdam. de)

${ }^{9}$ Japan Agency of Marine-Earth Science and Technology (saburos@jamstec.go.jp)

${ }^{10}$ University of Georgia (samarkin@uga.edu)

${ }^{11}$ University of Rhode Island (spivack@gso.uri.edu)

Large mound structures associated with cold-water coral ecosystems commonly occur along the continental slope off W Ireland (Porcupine Seabight). Over 1500 mounds of up to $5 \mathrm{~km}$ in diameter and $250 \mathrm{~m}$ height lie at water depths 600-900 m. To establish a depositional model for cold-water carbonate mounds, Challenger Mound and adjacent continental slope sites were drilled during IODP Expedition 307 in May 2005.

The Challenger mound succession is $130-150 \mathrm{~m}$ thick, and mainly consists of floatstone and rudstone facies formed of fine sediments and cold-water branching corals. Pronounced recurring cycles on the scales of several meters are recognized in carbonate content (up to $70 \%$ carbonate) and color reflectance, and are probably associated with Pleistocene glacial-interglacial cycles.

A role for methane seepage and subsequent anaerobic oxidation was discounted both as a hard-round substrate for mound initiation and as a principal source of carbonate within the mound succession. The zone of anaerobic oxidation of methane occurs in the sub-mound Miocene sediments as indicated by a broad sulfate-methane transition (approximately $50 \mathrm{~m}$ thick). Interstitial water profiles of sulfate, alkalinity, $\mathrm{Mg}$, and $\mathrm{Sr}$ suggest a tight coupling between carbonate diagenesis and microbial sulfate reduction. Depletion of $\mathrm{Mg}$ relative to $\mathrm{Ca}$ with increasing depth suggests that dolomite or another $\mathrm{Ca}-\mathrm{Mg}$ carbonate mineral is precipitating within the mound succession. Reaction of sulfide with siliciclastic iron-bearing minerals to form pyrite may further enhance diagenetic carbonate precipitation.

doi:10.1016/j.gca.2006.06.341

\section{High resolution climate records from stable isotopes and trace metals in mollusc shells from Gibraltar}

\author{
J.E. Ferguson ${ }^{1}$, D.A. FA ${ }^{2}$, T.C. Atkinson ${ }^{3}$, \\ R.N.E. Barton ${ }^{4}$, P. Ditchfield ${ }^{5}$, G.M. Henderson ${ }^{1}$, \\ J.C. FINLAYSON ${ }^{2}$ \\ ${ }^{1}$ Department of Earth Sciences, University of Oxford, Parks \\ Road, Oxford OX1 3PR, UK (julief@earth.ox.ac.uk) \\ ${ }^{2}$ The Gibraltar Museum, 18-20 Bomb House Lane, PO Box 939, \\ Gibraltar \\ ${ }^{3}$ Hydrogeology Research Group, Department of Earth Sciences, \\ University College London, Gower Street, London WC1E \\ 6BT, UK \\ ${ }^{4}$ Institute of Archaeology, University of Oxford, Beaumont \\ Street, Oxford OX1 2PG, UK \\ ${ }^{5}$ Research Laboratory for Archaeology and the History of Art, \\ University of Oxford, Dyson Perrins Building, South Parks \\ Road, Oxford OX1 3QY, UK
}

Climate records from Europe with seasonal resolution would allow investigation of the role of seasonality in controlling mean climate on diverse timescales, and of the evolution of climate systems such as the North Atlantic Oscillation (NAO). But achieving such seasonal resolution is difficult for regions outside the growth range of surface corals. Mollusc shells provide a possible archive and contain growth increments varying in scale from tidal to annual. Finding and dating sequences of mollusc shells spanning long periods of climate change is difficult, however, due to sealevel change and the destructional nature of most coastal environments.

In this study, we have made use of the habit of hominins on Gibraltar to collect molluscs for food over at least the last $120 \mathrm{kyr}$. Mollusc samples are found, sometimes in habitation levels, interspersed with layers of sediment blown into two caves (Gorham's and Vanguard Caves). Existing ${ }^{14} \mathrm{C}$, OSL, and U-series chronologies collected for archeological purposes provide a chronological framework for this suite of mollusc samples. Gibraltar is an interesting location for paleoclimate reconstruction due to its proximity to the boundary of modern day climate belts.

To gain a quantitative understanding of the local controls on stable isotopes and trace elements within Gibraltarian shells, we have initiated a water-sampling programme; emplaced a temperature and salinity logger near the sampling site; and marked live Patella and Mytilus with fluorescent dye to firmly establish growth rates and controls on chemical composition. We have also conducted stable-isotope and trace-element analysis of modern and fossil Patella and Mytilus shells by micromilling. Initial work has focused on recent shells, and on samples from a Neanderthal occupation level from approximately $115 \mathrm{kyr}$. Results allow an assessment of past changes in seasonality and of the utility of this archeological shell material as an archive for past change. 